\title{
Improving the probability of pregnancy in endometriosis cases: a study in patients undergoing in vitro fertilization
}

\author{
Taufik Jamaan, ${ }^{1,2}$ Arief Boediono, ${ }^{3}$ Trevino A. Pakasi, ${ }^{4}$ Farid A. Moeloek ${ }^{5}$ \\ ${ }^{1}$ Doctoral Study Program of Medical Sciences, Faculty of Medicine, Universitas Indonesia, Jakarta, Indonesia \\ ${ }^{2}$ Morula IVF, Bunda Hospital, Jakarta, Indonesia \\ ${ }^{3}$ Faculty of Veterinary Medicine, Bogor Agricultural University, Bogor, Indonesia \\ ${ }^{4}$ Department of Community Medicine, Faculty of Medicine, Universitas Indonesia, Jakarta, Indonesia \\ ${ }^{5}$ Department of Obstetrics and Gynecology, Faculty of Medicine, Universitas Indonesia, Jakarta, Indonesia
}

\begin{abstract}
Abstrak
Latar belakang: Endometriosis merupakan penyakit yang sering ditemukan melatarbelakangi infertilitas pada seorang wanita. Untuk meningkatkan angka kehamilan, pada kasus-kasus endometriosis yang diterapi program bayi tabung (IVF) dilakukan seleksi embrio. Penelitian ini ingin membuktikan efektifitas penilaian seleksi embrio terhadap keberhasilan kehamilan di sebuah rumah sakit di Jakarta.

Metode: Penelitian ini adalah sebuah studi epidemiologi klinik dengan rancangan potong-lintang pada pasien-pasien endometriosis yang datang pada kurun waktu 2007-2009 di sebuah rumah sakit di Jakarta. Pasien didiagnosis endometriosis menggunakan laparoskopi. Seleksi embrio dilakukan dengan metode penilaian morfologi dan jumlah sel. Data demografi, pemeriksaan laboratorium sampai kepada kehamilan diambil dari rekam medik untuk dianalisis lebih lanjut.

Hasil: Sebanyak 72 subjek mengikuti program IVF dalam kurun waktu penelitian ini yang datanya berhasil diambil. Ada satu kasus yang di-drop out karena oosit tidak matur. Sementara yang mengalami pembuahan ada 65 orang, dimana dua tidak dilakukan transfer embrio. Diantara mereka yang dilakukan transfer embrio, terjadi 26 kehamilan (36,1\%). Pada kasus endometriosis berat, kehamilan terjadi pada kualitas embrio excellent (50\%) dan good-moderate (16,7\%). Tetapi peluang tidak hamil yang ditemukan juga sama yaitu 50\% pada kasus endometriosis berat. Pada kasus endometriosis ringan-sedang, peluang kehamilan bila embrio excellent adalah 39\% dibandingkan good-moderate (25\%). Bila dibandingkan dengan jumlah embrio yang ditransfer, maka probabilitas kehamilan meningkat 50\% apabila ditransfer 3 embrio dibandingkan 1 atau 2 embrio.
\end{abstract}

Kesimpulan: Penelitian ini menunjukkan bahwa kualitas embrio dan jumlah embrio transfer berperan meningkatkan peluang kehamilan pada pasien-pasien IVF. Namun karena dibandingkan peluang tidak hamil yang tidak berbeda bermakna, diperlukan marker lain yang lebih sensitif untuk menilai kualitas embrio transfer. (Med J Indones. 2012;21:147-51)

\begin{abstract}
Background: Endometriosis is the most common condition underlying infertility in women. To increase the rate of pregnancy in women with endometriosis, embryo selection is performed during in vitro fertilization. This study aims to prove the effectiveness of embryo selection on the rate of pregnancy in a hospital in Jakarta.

Methods: This is a cross sectional clinical epidemiology study, performed on endometriosis patients who visited the hospital between 2007 - 2009. Patients were diagnosed with endometriosis using the laparoscopy technique. Embryo selection was performed by assessing the morphology and cell count.

Results: We were able to collect data from 72 subjects who underwent IVF during this research period. One subject was dropped out of the program due to immaturity of the oocyte. Successful fertilization was achieved for 65 subjects, but two of them did not undergo embryo transfer. Out of all the subjects undergoing embryo transfer, 26 subjects successfully became pregnant (36.1\%). In severe endometriosis cases, pregnancy was achieved with excellent quality embryos (50\%) and goodmoderate quality embryos $(16.7 \%)$; but the probability of failure to become pregnant was found to be the same (50\%). In mild-moderate endometriosis cases, the probability of pregnancy with excellent quality embryos was $39 \%$ compared to $25 \%$ chance with good-moderate quality embryos. Regarding the number of embryos that were transferred, we have found that the probability of pregnancy was 50\% higher when 3 embryos were transferred, compared to 1 or 2 transferred embryos.

Conclusion: This study shows that embryo quality and the number of transferred embryos are relevant to increase the probability of pregnancy in patients undergoing IVF. But because the probability of not achieving pregnancy is not significantly different, we need to find another marker that is more sensitive to assess the quality of embryo transfer. (Med J Indones. 2012;21:147-51)
\end{abstract}

Keywords: Embryo transfer, endometriosis, oocyte and embryo quality, pregnancy rate

At the moment, the rate of infertility found clinically is $10 \%-15 \%$ with a pregnancy rate still below $50 \%$. This prompts scientists to keep finding ways to improve assisted reproductive technology to increase the rate of pregnancy in women with infertility. Of all the techniques, IVF is still the most commonly used to solve infertility problems. ${ }^{1,2}$ To increase the pregnancy rate in in-vitro fertilization (IVF), the implantation 
rate of good quality embryos is increased by means of embryo selection before transfer. ${ }^{3,4}$

Until now, embryo quality is determined by assessing the morphology, scoring according to these parameters: blastomere count, blastomere regularity, fragmentation rate. Based on these parameters, embryo scoring is: excellent, good, moderate, and poor.

Aside from embryo selection, the severity of this condition also affects the fertilization success rate. About $10-15 \%$ of women in reproductive age have endometriosis, many of them also suffer from infertility. A number of studies show that patients with endometriosis have decreased oocyte and embryo quality. Out of all endometriosis cases, $35-50 \%$ experience pelvic pain and infertility. Endometriosis itself decreases the rate of pregnancy in IVF and increases the rate of miscarriage. 5,6

Embryo selection itself is subjective, depending on the skill and experience of the examiner. The question is, is this method still relevant to determine the success of IVF? Or do we need new assessment methods, especially in endometriosis cases? This study aims to correlate the quality of the oocyte and embryo to the probability of pregnancy in endometriosis patients undergoing IVF.

\section{METHOD}

\section{Study design and sampling method}

This is a cross sectional clinical epidemiology study within the setting of an IVF fertility clinic in a maternity hospital in Jakarta. Subject data for this study was retrieved through consecutive sampling from the medical records of patients with endometriosis who underwent IVF between January 2007 to December 2009. The diagnosis for endometriosis is established through laparoscopic surgery, and the severity determined according to the revised AFS scoring for endometriosis.

\section{Assessment method of embryo quality}

Assessment of embryo quality was performed morphologically. Scoring was performed based on these parameters: blastomere cell count, blastomere regularity, fragmentation rate. The scores were: excellent, good, moderate, and poor.

\section{Data analysis}

The data we collected were verified and descriptively analyzed using SPSS version 11.5. The relationship of two variables was tested to obtain the mean differences or proportion using chi-square test and stratified chisquare test.

\section{Research ethics}

Patients who visited this hospital have signed a medical consent form for the treatment of infertility and for the collection of secondary data as reviewed by the medical and medico-legal committee of the aforementioned hospital. The ethical review of this study was done by the Ethical Committee of the Medical Faculty of Universitas Indonesia.

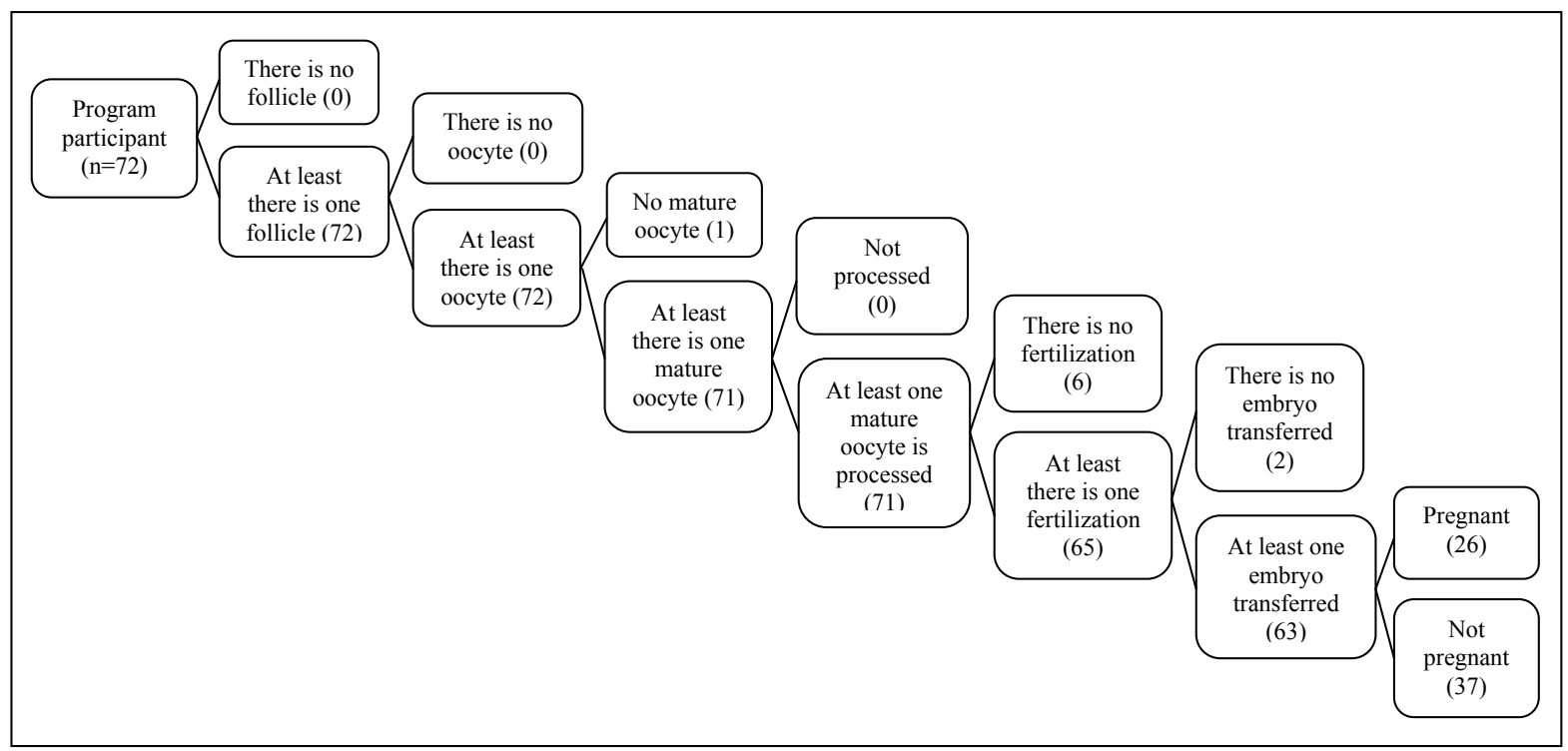

Figure 1. Conditions of endometriosis patients enrolled in the IVF program between 2007 and 2009 in Jakarta. Out of 72 patients, pregnancy occurred in 26 patients 


\section{RESULTS}

Figure 1 shows that there were 72 subjects with endometriosis that met our research criteria, with a median age of 35 years old (Table 1). We saw various responses to ovarian stimulation in patients with endometriosis. On average, we found 7.6 follicles developing in the (left/right) ovaries. At the time of ovum pick up (OPU) we found an average of 6.8 oocytes. One patient did not develop any mature oocytes (germinal vesicle stage) at the time of OPU. In six patients with mature oocytes, fertilization failed to occur. Two patients achieved successful fertilization but had poor quality embryos that were not adequate for transfer. Pregnancy was achieved in 26 patients $(36.1 \%)$ or $41.3 \%$ of all transferred embryos $(n=63)$ (Table 2$)$.

Table 1. Characteristics of research subjects

\begin{tabular}{lc}
\hline \multicolumn{1}{c}{ Variable $(\mathrm{n}=72)$} & Results \\
\hline Age $($ year $) *$ & $35 \pm 4,5$ \\
Dose of recombinant FSH (IU) & $300(50-375)$ \\
Length of injections (day)** & $9(3-12)$ \\
Estradiol level before OPU (pg) & $1070(120-4395)$ \\
Number of follicles ** & $7(1-20)$ \\
Number of oocytes** & $6(1-17)$ \\
Number of mature oocytes ** & $4(0-17)$ \\
\hline
\end{tabular}

* Mean $\pm \mathrm{SD}, * *$ Median (Min - Max)

Characteristics of research subjects with a mean age of 35 years old, and an age range of $25-45$ years old.

Table 2. Number and quality of oocytes and embryos

\begin{tabular}{lll}
\hline & $\mathrm{n}$ & $\%$ \\
\hline No mature oocytes & 1 & 1,4 \\
Mature oocytes, but not fertilized & 6 & 8,3 \\
Fertilized oocytes, but inadequate embryos & 2 & 2,8 \\
Embryo transfer $(+)$, pregnancy $(-)$ & 37 & 51,4 \\
Embryo transfer $(+)$, pregnancy $(+)$ & 26 & 36,1
\end{tabular}

Morphologically, the embryos that yielded the highest pregnancy rates were those of excellent and good quality. The probability of pregnancy with excellent and good quality embryos were almost the same $(p>0.05)$. Other than that, the number of embryos that were transferred yielded different results. The probability of pregnancy for patients who received three embryo transfers was higher than the initial proportion $(31.6 \%)$ compared to those who received two or only one embryo transfer. The first group was three times more likely to achieve pregnancy than the other two groups. The more embryos transferred, the higher the probability of achieving pregnancy, by $2 \%$ for two embryos transferred, and by $14 \%$ for three embryos transferred. Even so, the two results were not statistically significant. With the same amount of embryos transferred $(n=63)$, patients with severe endometriosis had a lower chance of pregnancy $(17.5 \%)$ compared to patients with mild to moderate endometriosis (31.7\%). With three embryos transferred, the chances of pregnancy increased to $50 \%$ in both patients with severe endometriosis and patients with mild to moderate endometriosis. Even so, the chances of not becoming pregnant were the same (Table 3 ).

Table 3. Percentage of pregnancy based on the quality and the number of transferred embryos

\begin{tabular}{ccc}
\hline Embryo Quality & $\begin{array}{c}\text { Not Pregnant } \\
\mathrm{n}(\%)\end{array}$ & $\begin{array}{c}\text { Pregnant } \\
\mathrm{n}(\%)\end{array}$ \\
\hline Embryo quality & $20(57,1)$ & $15(42,9)$ \\
Excellent & $13(56,5)$ & $10(43,5)$ \\
Good & $4(80)$ & $1(20)$ \\
Moderate & & \\
Number of embryos & $13(72,2)$ & $5(27,8)$ \\
One & $8(61,5)$ & $5(38,5)$ \\
Two & $16(50)$ & $16(50)$ \\
Three & & \\
\hline
\end{tabular}

The probability of achieving pregnancy was different for the various degrees of endometriosis cases. Table 4 describes how the quality and number of transferred embryos affect the chances of achieving pregnancy.

When multiple embryos were transferred, with one excellent quality embryo and others of good or moderate quality, then the probability of pregnancy was still good. Table 4 shows that in multiple embryo transfers, the probability of pregnancy increased when at least one embryo was of excellent quality.

\section{DISCUSSION}

The morphological assessment of the embryo is very subjective, depending on the personal skill of the embryologist and the equipment/ microscope used. Therefore, a biochemical marker in the embryo culture medium related to embryo quality with predictive value for implantation and pregnancy is needed..$^{5,7}$

Several studies have shown a relationship between the secretion/ expression of soluble human leukocyte 
Table 4. The probability of pregnancy in various degrees of endometriosis connected to the quality and number of transferred embryos

\begin{tabular}{cll}
\hline Degree of endometriosis & $\begin{array}{c}\text { Not Pregnant } \\
\mathrm{n}(\%)\end{array}$ & $\begin{array}{c}\text { Pregnant } \\
\mathrm{n}(\%)\end{array}$ \\
\hline $\begin{array}{c}\text { Severe (AFS 3-4) } \\
\text { Embryo quality } \\
\text { Excellent quality }\end{array}$ & \\
$\quad$ Good-moderate quality & $5(50)$ & $6(50)$ \\
Number of embryos transferred & & $1(16,7)$ \\
$\quad$ Three transferred embryos & $5(50)$ & $5(50)$ \\
$\quad$ Two-one transferred embryos & $12(54,4)$ & $10(45,6)$ \\
Embryo quality & & $9(39,1)$ \\
$\quad \begin{array}{l}\text { Excellent quality } \\
\text { Good-moderate embryo quality }\end{array}$ & $6(75)$ & $2(25)$ \\
Number of embryos transferred & & $11(50)$ \\
$\quad$ Three transferred embryos & $11(50)$ & $8(34,8)$ \\
$\quad$ Two-one transferred embryos & $15(65,2)$ & \\
\hline
\end{tabular}

antigen - G (sHLA-G) in the embryo culture medium and a higher implantation probability. Human leukocyte antigen $\mathrm{G}$ (HLA-G) is a unique antigen that is also expressed during implantation, showing the invasiveness of the placental cytotrophoblast. HLA-G is also believed to prevent the rejection of the trophoblast by the maternal immune system. Initially, HLA-G is expressed by the embryonic tropectoderm prior to implantation. Thus, the secretion of SHLA-G by the embryo is related to the success of implantation of the embryo. ${ }^{8,9}$

The biological age of the patient also affects the quality of the ovaries, because it diminishes ovarian reserves, aside from the effects of endometriosis.

Several studies have shown that in endometriosis cases, the rates of fertilization, implantation, and pregnancy are lower. The use of GnRH agonist and the collection of ovum transvaginally increases the success rate of the IVF process in infertility patients with endometriosis. Several mechanisms in endometriosis that may affect the outcome of $\operatorname{IVF}^{5,6,10}$ are: (1) the loss of access to the ovaries to obtain the ovum laparoscopically; (2) toxic effects of the embryo from the maternal serum; (3) increased peritoneal cytokines expression such as increased concentration of macrofags, prostaglandin, interleukin, and tumor necrosing factor (TNF); (4) the decrease of ovum development potential/ disturbance in folliculogenesis and oogenesis; (5) the decrease of VEGF expression; (6) the increase of follicular apoptosis; (7) the decrease of integrin expression (a molecule for cellular adhesion) in the endometrium, the increase of $\operatorname{IgG}, \operatorname{IgA}$, and lymphocytes in the endomterium, causing a decrease in endometrium receptors and a disturbance to embryo implantation.

There is a correlation between the speed of embryonic cellular division and the condition of the chromosomes. Speeds of cellular division that are too slow or too fast indicate the presence of chromosomal abnormalities, whether mosaic or aneuploidy. Munne also reported that chromosomal abnormalities after mitosis increases along with morphological changes in the embryo such as a decline in embryo development, multinucleation, fragmentation, and blastomere irregularity. ${ }^{11}$

In conclusion, this study shows that embryo quality and the number of transferred embryo is relevant to increase the probability of pregnancy in patients undergoing IVF. Further studies with a larger sample are needed to compare patients with endometriosis and patients without endometriosis to find the differences in oocyte quality and embryo quality, as well as to find a set of parameters or biochemical markers such as soluble HLA-G levels that can indicate the difference of embryo quality.

\section{Acknowledgments}

We would like to acknowledge the Director of Bunda Hospital, Menteng, Jakarta and the Head of Clinical Embryology Laboratory/ Morula IVF, Bunda Hospital, Jakarta for allowing access to their data for the purposes of our research. 


\section{REFERENCES}

1. Desai N, Filipovits J, Goldfarb J. Secretion of soluble HLA-G by day 3 human embryos associated with higher pregnancy and implantation rates: assay of culture media using a new ELISA Kit. Reprod Biomed Online. 2006;13(2):272-7.

2. Jamaan T, Anwar IN. Manual inseminasi intra uterus (IIU). Klinik Fertilitas Morula, Rumah Sakit Bunda Jakarta: Puspa Swara; Mei 2002, Vol. 1. Indonesian.

3. Yie SM, Balakier H, Motamedi G, Librach CL. Secretion of human leukocyte antigen-G by human embryos is associated with a higher in vitro fertilization pregnancy rate. Fertil Steril. 2005;83:30-6.

4. Szmigiel OS, Walknowska ER, Cybulski C, Plonka T, Lubinski J. Antigens HLA-G, sHLA-G and sHLA - class I in reproductive failure. Folia Histochem Cytobiol. 2007;45:137-41.

5. Bulleti C, Flamigni C, de Ziegler D. Implantation markers and endometriosis. Reprod Biomed Online. 2005;11(4):464-8.
6. Lutan D, Halim B, Adenin I. Endometriosis dan teknologi bantuan reproduksi. FIV dalam praktek klinik. Ed 1. Jun 2006. p. 107-11. Indonesian.

7. Warner CM, Comiskey M, Clisham PR, Brenner CA. Soluble HLA-G (sHLA-G) a predictor of IVF outcome? J Assist Reprod Genet. 2004;21:315-6.

8. Noci I, Fuzzi B, Rizzo R, Melchiorri L, Criscuoli L, Dabizzi S, et al. Embryonic soluble HLA-G as a marker of developmental potential in embryos. Hum Reprod. 2005;20:138-46

9. Van Lierop MJ, Wijnands F, Loke YW, Emmer PM, Lukassen HG, Braat DD, et al. Detection of HLA-G by a specific sandwich ELISA using monoclonal antibodies G233 and 56B. Mol Hum Reprod. 2002;8:776-84.

10. Jamaan T, Darmasetiawan MS, Anwar INC, Djuwantono T, Adenin I. Fertilisasi in vitro dalam praktek klinik (manual bayi tabung). Puspa Swara: Juni 2006, Vol. 1. Indonesian.

11. Olivennes F, Feldberg D, Liu HC, Cohen J, Moy F, Rosenwaks Z. Endometriosis: a stage by stage analysis - the role of in vitro fertilization. Fertil Steril. 1995;64:392-8. 